\title{
Калюжный В.Г. Геополитическая методология в условиях постмодерна
}

\author{
Kalyuzhny V.G. \\ Political methodology in a postmodern
}

Обосновывается актуальность анализируемой проблемы, рассматриваются и оцениваются морфологические особенности геополитических парадигм мирового порядка, их эвристический и адаптационный потенциал; исследуются проблемы развития общей теории мирового порядка

Ключевые слова: мировой порядок, геополитическое противоборство, политическая стабильность, безопасность

\section{Калюжный Вадим Геннадьевич}

Доктор политических наук, профессор Филиал Военного учебно-научного центра Военновоздушных сил «Военно-воздушная академия им. проф. Н.Е. Жуковского и Ю.А. Гагарина» 2. Сызрань, ул. Маршала Жукова, 1

\begin{abstract}
The urgency of the problem analyzed, reviewed and evaluated the morphological features of the geopolitical paradigm of world order, their heuristic and adaptive capacity; The problems of the development of the general theory of the world order
\end{abstract}

Key words: world order, geopolitical rivalry, political stability, security

\section{Kalyuzhny Vadim Gennagievich}

Doctor of Political Sciences, Professor

Branch Military Training and Research Center of the Air Force, "Air Force Academy named after prof. N.E. Zhukovsky and Yu.A. Gagarin"

Syzran, Marshal Zhukov St., 1

Более чем вековое развитие теории геополитики дает огромные возможности для анализа исторических событий, а также современных геополитических процессов становления субъектов геополитического противоборства, где ключевыми детерминантами выступают, с одной стороны, пространство земли (номос), с другой - контроль над ним и возможность его изменить.

Нарастающий процесс глобализации мира в XXI в. в сложной и противоречивой борьбе различных явлений, тенденций и интересов все более отчетливо выявляет фундаментальный императив выживаемости и безопасности человечества. Суть его состоит в выработке такой модели мироустройства, геополитическая конфигурация которой была бы устойчивой, стабильной, надежной, интегрирующей как национально-государственные, так и транснациональные интересы.

Для реализации механизма глобальной управляемости целесообразно обозначить его геополитические эксплицитные (явные) компоненты: границы распространения - геополитическое пространство; легитимность - осознанное, добровольное признание создающегося геополитического порядка субъ- 
ектами политической жизни; структурную иерархию - вертикаль властных субъектов мировой политики; динамичность - эффективное, поступательное развитие системы отношений в заданном направлении; стабильность - относительное постоянство сложившихся международных связей [1, с. 23].

Одной из ключевых характеристик создаваемой глобальной архитектуры мира выступает ее полюсность, связанная со степенью сопоставимости геополитических потенциалов субъектов мировой политики и с их способностью оказать достаточное влияние на систему международных отношений, а значит, облик мирового порядка в целом. В зависимости от количества ведущих партиципантов (участников) мировой политики выделяют «унипольную», «бипольную» и «полипольную» геополитические модели.

Для обоснования естественности становления унипольной модели мира используются различные теоретические концепции. Так, после открытия российским экономистом Н.Д. Кондратьевым долгосрочных циклов развития мирового хозяйства достаточно популярными стали теоретические аналогии на тему циклов мирового геополитического развития. В данном контексте особое место занимают разработки теории цикла гегемонии английским историком и геополитиком Питером Тейлором, предложившим свое видение смены циклов мировой гегемонии. По его мнению, мировая гегемония, какой-либо страны чрезвычайно редкий феномен, который случался всего несколько раз:

- гегемония торговой Венеции, ставшая в XV в. - первой половине XVI в. обширным колониальным государством - купеческой республикой;

- гегемония Нидерландов в XVII в. (перемещение торговых путей со Cредиземноморья в зону Атлантического океана (Новый Свет), создание «Вестиндской» и «Ост-индской» компаний);

- британская гегемония в середине XIX в. (через 200 лет после Нидерландской гегемонии);

- гегемония США в середине XX в. (через 100 лет после британской гегемонии).

Сущность данной концепции состоит в практически абсолютном доминировании одного из акторов геополитического противоборства в трех сферах общественной жизни: социально-экономической, общественно-политической и культурно-идеологической.

Любая гегемония в лице мировой державы базируется, прежде всего, на твердой экономике. Государство-гегемон добивается преимущества, в первую очередь, за счет инновационной деятельности, выпуска новой монопольной продукции, торговых преимуществ в мире, а также возможности финансового доминирования в мировой экономике, в результате чего государство с более высокими показателями производственной, торговой и финансовой эффективности становится мировым гегемоном.

В то же время доказывается законность гегемонизма в миропорядке с точки зрения международного права, возможность соединения двух начал унипольной гегемонии и демократических принципов развития. Государствагегемоны имеют возможность доминировать в межгосударственной системе без угрозы превращения их в империи, путем создания баланса сил и интере- 
сов таким образом, что предотвращается возможность формирования враждебной коалиции, способной угрожать геополитическому лидерству гегемона. Кроме того, государство-гегемон распространяет либеральные идеи, которые широко воспринимаются всем мировым сообществом (или его большей частью), что позволяет соперникам брать научно-технические и производственные достижения на вооружение, тем самым конкурируя в эффективности производства, вследствие чего лидерство государства-гегемона над его соперниками уменьшается сначала в производстве, а затем в торговле и финансах. Таким образом, происходит постепенная смена цикла геополитической гегемонии.

Американский исследователь мировых систем И. Валлерстайн экспериментально доказал связь циклов гегемонии государств с кондратьевскими циклами мировой экономики, выявив логическую цепь в динамике смены мировых порядков [2, с. 33-39]. Необходимым и достаточным условием существования гегемонических циклов является диссипативная возможность длительного контроля над капиталовложениями на мировом рынке, способствующая власти гегемона через создание широкой системы транспортных, коммуникационных, информационных и финансовых сетей, а также военных баз по всему миру.

Данная связь становится более очевидной, если свести в единую модель системы Кондратьева и Валлерстайна. Такая сдвоенная модель может показать, что политические механизмы являются неотъемлемой частью всеобщей переструктуризации мирового хозяйства, которая осуществляется на фазах подъема и спада указанных циклов.

Для конструирования униполярного мироустройства по американскому сценарию, на первый взгляд, существуют серьезные основания экономического, внешнеполитического, военно-стратегического, идеологического и психофизиологического характера, однако есть достаточно веские аргументы и суждения против такой парадигмы мирового геополитического развития. Данная структура нестабильна, главным образом, по причине неизбежного сползания единственного мирового лидера к агрессивно-силовым способам воздействия на окружающую среду, искушения реализовать свою превосходящую геополитическую мощь в создание системы собственного мирового господства. Имевшие место в истории попытки построения мировых империй сопровождались крупными международными военными конфликтами, окончились неудачей в силу истощения ресурсов и возможностей и не смогли стать основой для стабильного порядка. Сомнительно утверждать, что сегодня это удастся США. Геополитический порядок, основанный на стремлении подчинить всех интересам одной, пусть даже и самой мощной державы, не отвечает общепринятым стандартам и нормам международного права и вызывает вполне справедливое противодействие со стороны других государств.

Существует и другое мнение. Такие ученые-политологи, как С. Коэн, А. Богданов, а также современный политический истеблишмент ряда государств (включая Российскую Федерацию) доказывают, что обеспечение структурно стабильного мирового устройства достигается в целом за счет его полиполяр- 
ности и сбалансированности между ведущими центрами влияния. Концепция многополярного мира и нового международного порядка имеет фундаментальное значение для цивилизованного конструирования международных отношений. Но есть ряд ученых (М. Райзман, К. Алдред, У. Кристофер и др.), которые не согласны с подобным утверждением, считая полиполярную структуру отношений с множеством центров силы как раз самой неустойчивой, хаотической системой («борьбы всех против всех»). Это аргументируется тем, что из-за асинхронного развития государств между ними возникает неравенство, вследствие чего работает «закон силы», который гласит: «как только государство достигает уровня экономической мощи и военного потенциала, адекватного мощи и потенциалу ведущих государств мира, оно требует для себя нового статуса, означающего передел сфер мирового влияния». Например, появление в XXI в. нового всевозрастающего центра силы и влияния в лице Китайской Народной Республики, способной уже сегодня «подмять под себя» достаточное количество стран Азиатско-Тихоокеанского региона и не только.

Есть и другие суждения. Так, американский ученый А.Батлер предполагает, что система обладает наибольшей степенью стабильности только в условиях биполярной структуры [3, с. 15-21]. Так, Ялтинско-Потсдамская система международных отношений была ориентирована на данную структуру мира, представляя собой вариант межгосударственного взаимодействия, являясь частью Вестфальской модели. В истории были и другие модели межгосударственного взаимодействия, например, после окончания Первой мировой войны сложилась Версальско-Вашингтонская система международных отношений. Все эти системы исходили фактически из представлений о мировом порядке как о взаимодействии отдельных государств, руководствуясь в своем развитии тремя гоббсовскими положениями:

1) достижение и обеспечение безопасности государства;

2) удовлетворение экономических требований политически значимых слоев населения;

3) повышение престижа государства на международной арене.

В связи с этим возможно предположить, что биполярность является не переходным состоянием в мировой политике, а структурной основой любого мирового порядка, любой архитектуры международной безопасности, и базируется на геополитических законах и принципах планетарного дуализма.

Процесс ломки Вестфальской модели мира и Ялтинско-Потсдамской системы международных отношений по-разному проявляется в разных странах и регионах. Наряду с моделью «государственно-центричного мира» [4] существуют системы, в которых активно действуют негосударственные и надгосударственные акторы, в связи с чем встает вопрос о политической стабильности, которая является основной задачей на этапе смены парадигмы управления обществом.

Сегодня нет единого мнения по поводу того, что представляет собой политическая стабильность, отсюда и различные концептуальные трактовки этого понятия, такие как: 
- устойчивое состояние политической системы, основанное на способности реагировать на поступающие в нее требования и принимать достаточно быстрые и эффективные решения;

- согласие основных социальных и политических сил по поводу целей и методов общественного развития;

- состояние политической жизни общества, проявляющееся в устойчивом функционировании всех имеющихся в обществе политических институтов, связанное с их сохранением и совершенствованием;

- совокупность упорядоченных политических процессов, обеспечивающих бытие и развитие политических субъектов в политической системе, и др.

Можно предположить, что основным смыслообразующим признаком политической стабильности, выражающим ее суть, выступает словосочетание «устойчивое состояние», при котором система обладает качествами эффективного функционирования и развития при сохранении своей структуры. При этом политическая стабильность - не статическая величина, а величина, обладающая динамикой, выражающаяся в имманентном достижении системой состояния баланса в постоянно изменяющихся условиях. Содержанием политической стабильности выступают такие обязательные элементы, как гражданский мир и порядок, легитимность и прочность власти, а также ее эффективность как способность выполнять соответствующие жизнеобеспечивающие функции.

На качественное состояние политической стабильности влияют многие факторы, к которым можно отнести: экономический рост государства; наличие действенных правовых регуляторов общественной жизни; гражданское общество, от уровня развития которого зависит степень политического сознания, уровень политической культуры населения. Также на этапе достижения политической стабильности очень важно эмоционально-психологическое настроение граждан, выражающееся в доверии к существующей политической системе, политической этике, моральной и деятельностной поддержке властвующей элиты и т.д. Население должно разделять ценности, которые политическая власть ставит в качестве идеологических ориентиров, а значит, эти ценности должны приниматься подавляющим числом граждан, отражаться в их сознании и поведении в виде «свободной лояльности».

Мир в будущем будет носить относительно устойчивый, но недостаточно равновесный характер, т.к. накопленный за огромный период эволюционного развития геополитический ресурс, придавая мировому порядку эксплицитнодиссипативную (мнимую) устойчивость в своем перманентном развитии, одновременно будет выражать определенную уязвимость, поскольку внутренне изначально уже скрывает в себе суфизматические элементы тотальной деструкции. В связи с таким умозаключением можно предположить, что в недалеком будущем ведущим механизмом, обеспечивающим и гарантирующим стабильность международной системы, наряду с государствами, обладающими правом суверенитета, будут международные организации. Именно в рациональном начале заложен главный смысл создания и функционирования различных международных объединений, способных с помощью единых процедур 
и добровольного членства выработать тактику и стратегию совместного поведения. Подтверждая данный вывод, можно привести слова известного российского ученого Г.В. Мальцева, который говорил, что, «наступает эра организаций и организационной власти, с ее изощренным рациональным инструментарием» $[5$, с. 303].

Усиление роли международных организаций сочетается с другой тенденцией развития современных международных отношений, выстраивающих мировой порядок, - появлением новых партиципантов, как легальных (формальных и неформальных), так и нелегальных. По всей видимости, это связано с продолжающейся модернизацией современного мироустройства и прямым следствием глобализации - построением сетевых структур, что позволяет уже сейчас говорить о сетевом характере мира, особенно в информационной сфере. Складывающаяся глобальная политическая система лишена важного структурирующего элемента, который был бы способен уравновесить центры силы, выступить в качестве инструмента преодоления неизбежных противоречий в мировом масштабе, в том числе приводящих к кризису государственности. Таким элементом мог бы стать формирующийся идеологический контур глобального порядка, акцентирующий социальную проблематику, выстраивающий отношения между стержневыми государствами, основанными на принципах баланса интересов, социального равенства, справедливости и консенсуса.

Достаточно остро стоит вопрос социальной справедливости и несправедливости формирующегося глобального порядка. «Понятие справедливости связано с представлениями о государстве, так как право, служащее мерилом справедливости, является регулирующей нормой политического общения», отмечал Аристотель [6, с. 38]. Сегодняшний кризис справедливости, отход от понимания справедливости в качестве «государственного блага» является не только проявлением общего кризиса государства, но и результатом пошатнувшегося статуса и авторитета международного права, претендующего на роль главного регулятора внешнеполитических взаимодействий между странами. Между тем именно принцип справедливости обеспечивает достойный уровень жизни населения, смягчает социальное неравенство, является одним из главных условий международной политической стабильности.

Базовой целью и определяющими дефинициями любого государства является обеспечение безопасности как отдельной личности, так и всего общества от возникающих вызовов, опасностей и угроз - эта степень защищенности является системным императивом формирующегося мирового порядка. Реалиями сегодняшнего дня стали: изменение соотношения сил в глобальном и региональном масштабах, возникновение новых и расширение существовавших интеграционных групп, увеличение числа разного рода конфликтов. Эти кардинальные изменения серьезно трансформировали геополитический ландшафт и в настоящее время способствуют образованию своего рода санитарных, или дисконтинуальных кордонов (поясов) вокруг мировых, региональных и субрегиональных держав.

Еще вчера при возникновении того или иного вызова, опасности или угрозы человек мог воспользоваться историческим опытом выработки необ- 
ходимых мер: в конце XX в. достаточно хорошо работали традиционные инструменты мировой политики, позволявшие разрешать вооруженные конфликты любых форм, обеспечивая безопасность общества. Четкие правила взаимодействия в условиях двух враждующих полюсов гарантировали достаточно низкий уровень преступности и криминализации общества и мира в целом - личной безопасности человека мало что угрожало.

В настоящее время, учитывая новый характер вызовов и угроз, можно предположить, что в ближайшем будущем будут пересмотрены подходы к формированию концепции национальной безопасности ряда государств, в том числе Российской Федерации. Сегодня крупномасштабный терроризм, распространение ядерного оружия, а также внедрение информационных технологий, трансформирующих саму структуру мирового сообщества, требуют совершенно иного подхода к управлению мировыми делами - обеспечению всеобщей (глобальной) безопасности мирового сообщества.

Гарантии всеобщей безопасности - это первейшая потребность, которую призван обеспечить формирующийся мировой порядок, как это было и остается в условиях суверенных, независимых государств. Ни подход с позиции права сильного, ни подход, направленный на поиск консенсуса, не дают убедительного ответа на вопрос: как справиться с нарастающей волной многочисленных глобальных проблем? Перед всем человечеством стоит сегодня главная задача, как прийти к мировому порядку, в меньшей степени опирающемуся на силу и в большей - на иные гуманитарные средства, руководствуясь в своем развитии не конфронтационными, коалиционными принципами «коллективной безопасности», а новой миросистемой глобальной архитектуры безопасности, основанной на соблюдении общепризнанных принципов и норм международного права, исключающих любое применение силы.

Переход мира в новую геополитическую эпоху, кардинальная перестройка политической геометрии мирового пространства выявили общую для всех стран и народов ключевую потребность, смысл которой заключен в выработке новой, соответствующей реалиям сегодняшнего дня универсальной парадигмы геополитического устройства, отвергающей принцип «баланса сил» и основывающейся на консенсусном суверенном равенстве и партнерстве всех акторов мирового развития.

Без преувеличения можно сказать, что от того, насколько консолидированно и слаженно мировое сообщество будет использовать свой потенциал в построении нового мирового порядка в условиях глобализации, будет зависеть облик нашей планеты в будущем. Имеются все основания для предположения того, что императив солидарных действий перед лицом общих опасностей возобладает над рефлексом «спасения в одиночку» и человечество сделает выбор в пользу демократического полиполярного миропонимания, гарантирующего поступательное развитие и равную безопасность для всех государств. 
2. Валлерстайн И. Глобализация или Возраст Перехода? // Международная социология. 1999. № 2. C. 33-39.

3. Батлер А. Контуры мира в первой половине ХХІ века и чуть далее (теория) // Международная экономика и международные отношения. 2002. № 1. С. 15-21.

4. Rosenau J.N., Czempiel E.O. Governance without government: order and change in world politics. Cambridge, 1992.

5. Мальцев Г.В. Понимание права. Подходы и проблемы. М., 1999. 419 с.

6. Аристотель. Политика. Афинская полития. М., 1997. 72 с.

(C) 2014, Калюжный В.Г.

Геополитическая методология в условиях постмодерна
(C) 2014, Kalyuzhny V.G.

Political methodology in a postmodern 